Keywords: Etn phosphoglycerides; phorbol ester; protein kinase C; ethanolamine; prostate cancer epithelial cell lines; phospholipase D

\title{
Phorbol ester stimulates ethanolamine release from the metastatic basal prostate cancer cell line PC3 but not from prostate epithelial cell lines LNCaP and P4E6
}

\author{
J Schmitt ${ }^{1}$, A Noble ${ }^{1,2}$, M Otsuka ${ }^{1}$, P Berry ${ }^{1,2}$, N J Maitland ${ }^{1,2}$ and M G Rumsby ${ }^{\star, 1}$ \\ ${ }^{1}$ Department of Biology, University of York, York, YO10 5DD, UK and ${ }^{2}$ Yorkshire Cancer Research Laboratory, University of York, \\ York YO10 5DD, UK
}

Background: Malignancy alters cellular complex lipid metabolism and membrane lipid composition and turnover. Here, we investigated whether tumorigenesis in cancer-derived prostate epithelial cell lines influences protein kinase C-linked turnover of ethanolamine phosphoglycerides (EtnPGs) and alters the pattern of ethanolamine (Etn) metabolites released to the medium.

Methods: Prostate epithelial cell lines P4E6, LNCaP and PC3 were models of prostate cancer (PCa). PNT2C2 and PNT1A were models of benign prostate epithelia. Cellular EtnPGs were labelled with $\left[1-{ }^{3} \mathrm{H}\right]$-Etn hydrochloride. PKC was activated with phorbol ester (TPA) and inhibited with Ro31-8220 and GF109203X. D609 was used to inhibit PLD (phospholipase D). [ ${ }^{3} \mathrm{H}$-labelled Etn metabolites were resolved by ion-exchange chromatography. Sodium oleate and mastoparan were tested as activators of PLD2. Phospholipase D activity was measured by a transphosphatidylation reaction. Cells were treated with ionomycin to raise intracellular $\mathrm{Ca}^{2+}$ levels.

Results: Unstimulated cell lines release mainly Etn and glycerylphosphorylEtn (GPEtn) to the medium. Phorbol ester treatment over $3 \mathrm{~h}$ increased Etn metabolite release from the metastatic PC3 cell line and the benign cell lines PNT2C2 and PNT1A but not from the tumour-derived cell lines P4E6 and LNCaP; this effect was blocked by Ro31-8220 and GF109203X as well as by D609, which inhibited PLD in a transphosphatidylation reaction. Only metastatic PC3 cells specifically upregulated Etn release in response to TPA treatment. Oleate and mastoparan increased GPEtn release from all cell lines at the expense of Etn. lonomycin stimulated GPEtn release from benign PNT2C2 cells but not from cancer-derived cell lines P4E6 or PC3. Ethanolamine did not stimulate the proliferation of LNCaP or PC3 cell lines but decreased the uptake of choline (Cho).

Conclusions: Only the metastatic basal PC3 cell line specifically increased the release of Etn on TPA treatment most probably by PKC activation of PLD1 and increased turnover of EtnPGs. The phosphatidic acid formed will maintain a cancer phenotype through the regulation of mTOR. Ethanolamine released from cells may reduce Cho uptake, regulating the membrane PtdEtn:PtdCho ratio and influencing the action of PtdEtn-binding proteins such as RKIP and the anti-apoptotic hPEBP4. The work highlights a difference between LNCaP cells used as a model of androgen-dependent early stage PCa and androgenindependent PC3 cells used to model later refractory stage disease.

The plasma membrane of prostate cancer $(\mathrm{PCa})$ cells provides a primary contact surface with basement membrane, other cancer cells and stroma as well as with immune cells. Malignancy alters the fatty acid composition of complex lipids in such membranes driven by a switch to anabolic metabolic pathways (Suburu and Chen 2012). Prostate cancer cells and transformed prostate epithelial cell lines also contain elevated levels of choline (Cho) and ethanolamine (Etn) metabolites indicative of changes in

*Correspondence: Dr MG Rumsby; E-mail: mgr1@york.ac.uk

Received 24 April 2014; revised 9 July 2014; accepted 21 July 2014; published online 19 August 2014

(c) 2014 Cancer Research UK. All rights reserved 0007-0920/14 
phosphatidylcholine (PtdCho) and ethanolamine phosphoglyceride (EtnPG) turnover (e.g., Ackerstaff et al, 2001, 2003; Swanson et al, 2008; Komoroski et al, 2011) as reported for other cancer cells and transformed cell lines (e.g., Aboagye and Bhujwalla, 1999; Ackerstaff et al, 2001, 2003; Herminghaus et al, 2002; Iorio et al, 2005; Glunde et al, 2006; Eliyahu et al, 2007; Podo et al, 2007). In PCa cells, levels of phosphorylEtn (PEtn) exceed those of phosphorylCho (Podo, 1999; Swanson et al, 2008; Komoroski et al 2011). Further, the glycerylphosphorylEtn (GPEtn) to glycerylphosphorylCho ratio increases in $\mathrm{PCa}$ as with many transformed cells (Singer et al, 1995; Bell and Bhakoo, 1998; Podo, 1999; Ackerstaff et al, 2003; Swanson et al, 2008; Komoroski et al, 2011). Such changes in Etn metabolites reveal that turnover of EtnPGs, as well as that of PtdCho, is altered in tumorigenesis. Serum EtnPG levels are also raised in PCa (Zhou et al, 2012).

These changes in Cho and Etn metabolite levels in malignant cells occur because of the increased expression and/or activity of enzymes regulating PtdCho and EtnPG metabolism including Cho/ Etn kinase (Cho/EtnK), PLD, PtdCho-specific phospholipase C (PtdCho-PLC) and phospholipase A2 (PLA $)$ (e.g., Ramirez de Molina et al, 2002, 2008; Foster and Xu, 2003; Foster, 2009; Iorio et al, 2010; Dong et al, 2010; Caiazza et al, 2011). Increased expression of Cho/Etn transporters and faster rates of Cho or Etn uptake (Katz-Brull et al, 2002; Eliyahu et al, 2007; Mintz et al, 2008; Iorio et al, 2010) also contribute to altered phospholipid metabolite levels in transformed cells. Ethanolamine phosphoglycerides are substrates for PLD and their turnover by PLD increases on PKC activation indicating involvement of PLD1 (Kiss and Anderson, 1989; Hii et al, 1991; Kiss and Tomono, 1995). PtdEtn may even be an exclusive PLD substrate in some cell lines (Kiss et al, 1994). Because tumorigenesis influences PKC-stimulated PtdCho turnover in prostate epithelial cell lines (Rumsby et al, 2011), we have now investigated whether EtnPG turnover is linked to PKC and is also altered by tumorigenesis.

\section{MATERIALS AND METHODS}

Cell culture. Benign prostate epithelial cell lines PNT2C2 and PNT1A and the cancer-derived cell line LNCaP were cultured in RPMI1640 with added glutamine, HEPES and 10\% FBS (R10). The cancer-derived P4E6 cell line was cultured in keratinocyte serumfree medium with pituitary extract and epidermal growth factor additives and 2\% FBS (K2A). The cancer-derived metastatic PC3 cell line was cultured in Hams F-12 with 7\% FBS (F7). Passage numbers were: $\quad$ PNT2C $<150 ; \quad \mathrm{PNT} 1 \mathrm{~A}<80$; $\quad \mathrm{P} 4 \mathrm{E} 6<50$; $\mathrm{LNCaP}<50$; $\mathrm{PC} 3<50$. Cells were passaged by rinsing with Trissaline, releasing with Tris-trypsin for $10 \mathrm{~min}$ at $37^{\circ} \mathrm{C}$ and pelleting in R10 to inactivate trypsin followed by resuspension in their normal growth medium for continued growth, or in low serum medium (e.g., R2.5, F2.5, K2) or medium lacking serum for experiments. All cell lines were Mycoplasma-free and were genotyped (Powerplex 16, Promega, Southampton, UK; Cat. No. DC6531) to ensure identity and genomic stability.

Effect of cell density on basal Etn metabolite release. PNT2C2 cells were seeded (in triplicate) into 24 -well plates at 2.5-, 5-, $7.5 \times 10^{4}$ and $1 \times 10^{5}$ in $0.5 \mathrm{ml} \mathrm{R} 2.5$ medium and labelled with $0.5 \mu \mathrm{Ci}\left[1-{ }^{3} \mathrm{H}\right]-$ Etn chloride (American Radiolabelled Chemicals, Stevenage, UK) per well for $36 \mathrm{~h}$. Labelling medium was removed, cells were rinsed once in warm R0 and then incubated at $37^{\circ} \mathrm{C}$ for $60 \mathrm{~min}$ in R0. Cells were further rinsed twice with warm R0 to remove released $\left[{ }^{3} \mathrm{H}\right]$-Etn-labelled metabolites. Finally, $0.5 \mathrm{ml}$ R0 containing $1 \mathrm{~mm}$ unlabelled Etn and PEtn was added. Basal release of Etn metabolites was monitored by taking $30 \mu \mathrm{l}$ aliquots of medium at $\mathrm{T}=0,1,2$ and $3 \mathrm{~h}$ for scintillation counting (below) and by replacing medium removed with fresh $\mathrm{R} 0$ to maintain volume. After $3 \mathrm{~h}$, remaining medium was centrifuged to pellet cell debris. Etn metabolites released from cells were resolved on ion exchange columns as below.

$\left[{ }^{3} \mathbf{H}\right]$-Etn metabolite release. Cells $\left(7.5 \times 10^{4}\right)$ were seeded in triplicate into 24 -well plates in R2.5, F2.5 or K2 as appropriate and labelled with $\left[1-{ }^{3} \mathrm{H}\right]-$ Etn hydrochloride as above. LNCaP cells were cultured on poly-L-lysine-coated wells or amine plates (BD, Oxford, UK) to improve adhesion during rinses. Cells were used just sub-confluent to minimise changes due to contact inhibition or cell cycle effects. Labelled cells were rinsed as above and incubated with $0.5 \mathrm{ml}$ serum-free medium containing $1 \mathrm{~mm}$ Etn hydrochloride and $1 \mathrm{~mm}$ PEtn hydrochloride (to minimise rapid $\left[{ }^{3} \mathrm{H}\right]$-Etn reuptake) plus PKC activators/inhibitors (see Figure legends) per well (Rumsby et al, 2011). Thirty microlitre aliquots of medium were removed from wells at $\mathrm{T}=0$ and at times indicated in figures; fresh medium ( $+/-$ inhibitors) was added to wells to maintain volume. Aliquots were centrifuged at 13000 r.p.m. to pellet any cell debris; duplicate $10 \mu \mathrm{l}$ aliquots were then removed into Top Count plates for scintillation counting with $100 \mu \mathrm{l}$ Microscint-20 (Perkin-Elmer, Beaconsfield, UK). Mean c.p.m. values from triplicate wells were calculated $+/-$ s.d. $(n=6)$. At the end of experiments, media were centrifuged and frozen for later Etn metabolite analysis.

Separation of Etn and Cho in medium. Aliquots of media were spotted onto Kieselgel G TLC plates (Merck Millipore, Nottingham, UK) with standards of $\left[1-{ }^{3} \mathrm{H}\right]$-Etn and $\left[{ }^{3} \mathrm{H}\right]$-Cho in adjacent lanes. Plates were dried and developed in methanol (MeOH): $0.5 \% \mathrm{NaCl}$ $(1: 1, v / v)$. After drying, lanes with standards and media were divided into nine $1.5-\mathrm{cm}$ sections. Adsorbent in each section was scraped into scintillation vials with $2 \mathrm{ml}$ Ultima Gold XR scintillant (Perkin-Elmer) to detect positions of standards indicating resolution of Etn and Cho in the media lanes.

Separation of PtdEtn and PtdCho. $\left[1-{ }^{3} \mathrm{H}\right]$-Etn-labelled cells remaining from release experiments above were extracted once with $0.5 \mathrm{ml} \mathrm{MeOH}$ and twice with $0.5 \mathrm{ml}$ chloroform $\left(\mathrm{CHCl}_{3}\right): \mathrm{MeOH}(1: 2 \mathrm{v} / \mathrm{v})$ and $0.5 \mathrm{ml} \mathrm{CHCl}_{3}: \mathrm{MeOH}(1: 1 \mathrm{v} / \mathrm{v})$ to recover total lipids. Solvent extracts were pooled and dried under nitrogen. Lipids were redissolved in $\mathrm{CHCl}_{3}: \mathrm{MeOH}(2: 1 \mathrm{v} / \mathrm{v})$ and triplicate aliquots resolved by TLC on Kieselgel $\mathrm{H}$ plates in $\mathrm{CHCl}_{3}: \mathrm{MeOH}: \mathrm{H}_{2} \mathrm{O}$ (5:2:1 v/v) against authentic PtdEtn and PtdCho standards (Lipid Products, Nutfield, UK). Positions of lipids were identified with iodine vapour. Appropriate areas of adsorbent containing PtdCho and PtdEtn were scraped into vials with $2 \mathrm{ml}$ scintillant (as above) for scintillation counting.

Resolution of GPEtn, PEtn and Etn. Etn metabolites were resolved by ion exchange chromatography (Kiss et al, 1994). Radioactivity in triplicate $0.5 \mathrm{ml}$ aliquots of each fraction was measured by scintillation counting to calculate total d.p.m./ fraction. Sodium oleate $(1 \mathrm{~mm})$ in samples had no effect on the elution pattern of GPEtn, PEtn and Etn from columns (results not shown).

Transphosphatidylation. Phospholipase D activity was measured by detection of PtdBut formation (Rumsby et al, 2011) with TLC plates developed in $\mathrm{CHCl}_{3}: \mathrm{MeOH}$ : acetic acid $(65: 15: 2, \mathrm{v} / \mathrm{v})$ after Chahdi et al, (2003). Lipids were detected with iodine vapour and areas of adsorbent corresponding to PtdBut, phosphatidic acid $(\mathrm{PtdOH})$ and PtdCho were scraped into vials with $2 \mathrm{ml}$ scintillant to measure radioactivity. Means of triplicate d.p.m. values were calculated and PtdBut d.p.m. expressed as a \% of PtdCho d.p.m. Cells in 6-well plates plus controls were treated with phorbol ester (TPA), $1 \mathrm{~mm}$ sodium oleate, $15 \mu \mathrm{M}$ mastoparan 7 or the inactive form M17 for $30 \mathrm{~min}$ prior to extraction.

Etn and Cho metabolite release in the presence of serum. PNT2C2 cells $\left(7.5 \times 10^{4}\right)$ in R2.5 in 24-well plates were labelled 
with either $0.5 \mu \mathrm{Ci}\left[1-{ }^{3} \mathrm{H}\right]$-Etn or $\left[\right.$ methyl- $\left.{ }^{3} \mathrm{H}\right]$-choline chloride

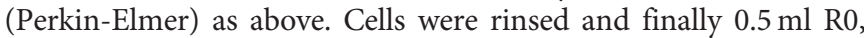
R10, R0/TPA or R10/TPA added to triplicate wells. Choline or Etn metabolite release was then followed up to $180 \mathrm{~min}$ as above.

Sodium oleate and mastoparan. Sodium oleate (Sigma-Aldrich, Poole, UK) was suspended in medium at $1 \mathrm{~mm}$, warmed to $37^{\circ} \mathrm{C}$ and dispersed by sonication. The $\mathrm{pH}$ was adjusted to 7.4 with $0.1 \mathrm{M}$ $\mathrm{HCl}$ and the stock $1 \mathrm{~mm}$ solution diluted with serum-free medium as appropriate. Oleic acid (Sigma-Aldrich) was dissolved in DMSO and diluted in medium for use. Mastoparan 7 (Cambridge Bioscience, Cambridge, UK) and inactive Mastoparan 17 (SigmaAldrich) were dissolved in sterile water to $3 \mathrm{~mm}$ and then diluted to 5 and $15 \mu \mathrm{M}$ in medium. Cells were labelled with $\left[1-{ }^{3} \mathrm{H}\right]$-Etn as above.

Ionomycin. Stock $10 \mathrm{~mm}$ ionomycin was diluted in DMSO to $1 \mathrm{~mm}$ and added to medium over cells to give final concentrations of $1 \mu \mathrm{M}$ and $2.5 \mu \mathrm{m}$. Basal medium contained DMSO.

Proliferation studies. Effects of Etn and epidermal growth factor on LNCaP and PC3 cell proliferation were monitored after $48 \mathrm{~h}$ by MTS (Promega). Stimulation of DNA synthesis by Etn and EGF was also examined using the Click-iT EdU assay with Alexa Fluor azide as described by the manufacturer (Invitrogen, Paisley, UK).

Effect of Etn on Cho uptake by PC3 cells. PC3 cells $\left(7.5 \times 10^{4}\right)$ were cultured overnight in wells of 24-well plates in F7 medium. The F7 was then replaced with $0.5 \mathrm{ml}$ Hanks balanced salt solution (HBSS) and cells incubated for $60 \mathrm{~min}$ at $37^{\circ} \mathrm{C}$. HBSS $(0.5 \mathrm{ml})$ containing $0-50 \mu \mathrm{m}$ Etn was then added. After $5 \mathrm{~min}, 10 \mu \mathrm{l}$ of $250 \mu \mathrm{M}$ Cho containing $1 \mu \mathrm{Ci}\left[{ }^{3} \mathrm{H}\right]$-Cho was added to each well giving a final Cho concentration of $5 \mu \mathrm{M}$ (Lipton et al, 1988). Cells were incubated for $3 \mathrm{~min}$ (Lipton et al, 1988) prior to rinsing three times with cold $\left(4^{\circ} \mathrm{C}\right)$ HBSS. Cells were completely drained of rinse medium and solubilised in $200 \mu$ l RIPA buffer. Radioactivity in triplicate $20 \mu \mathrm{l}$ aliquots was measured by scintillation counting.

Statistics. Statistical significance was determined by Student's two-tailed $t$-test as previously (Rumsby et al, 2011). The symbols *, $* *$ and ${ }^{* * *}$ denote statistically significant increases or decreases between unstimulated and stimulated cells or between stimulated and inhibited cells at $P<0.01, P<0.001$ and $P<0.0001$, respectively.

\section{RESULTS}

Prostate epithelial cell lines do not incorporate $\left[1-{ }^{3} \mathrm{H}\right]-\mathrm{Etn}$ into PtdCho. Incubation of prostate epithelial cell lines with $\left[1-{ }^{3} \mathrm{H}\right]-$ Etn for $36 \mathrm{~h}$ followed by lipid extraction and TLC resolution of PtdEtn and PtdCho indicated that between 93 and $97 \%$ of the $\left[{ }^{3} \mathrm{H}\right]$-label was associated with PtdEtn with only 3 and $6.7 \%$ being detected in PtdCho (Table 1). $\left[{ }^{3} \mathrm{H}\right]$-label detected in Cho released into medium from $\left[1-{ }^{3} \mathrm{H}\right]$-Etn-labelled PNT2C2, PNT1A and PC3 cells after 3-h experiments was also negligible compared with that in Etn (results not shown). Thus, any Cho metabolites released to the medium because of PtdCho turnover (Rumsby et al, 2011) will not interfere with quantitation of $\left[{ }^{3} \mathrm{H}\right]$-Etn metabolites.

Basal release of Etn metabolites is not influenced by cell density. After $36 \mathrm{~h}$ of labelling with $\left[1-{ }^{3} \mathrm{H}\right]-\mathrm{Etn}, \mathrm{PNT} 2 \mathrm{C} 2$ cells initially seeded at $1 \times 10^{5}$ cells per well were fully confluent completely covering the well surface whereas cells seeded initially at $2.5 \times 10^{4}$ cells were only $60-70 \%$ confluent. The basal ratio of GPEtn:PEtn:Etn metabolites released by non-confluent and confluent PNT2C2 cells was essentially the same at 3:1:6 (see PNT2C2 in Figure 4) indicating that the ratio of Etn metabolites released was not influenced by variation in initial cell density.
Basal and TPA-stimulated Etn metabolite release. Unstimulated cell lines all released $\left[{ }^{3} \mathrm{H}\right]$-Etn metabolites to the medium in a typical 6-h time course (Figure 1), the longest experimental period. This basal $\left[{ }^{3} \mathrm{H}\right]$-Etn metabolite release was linear with time. Phorbol ester stimulated $\left[{ }^{3} \mathrm{H}\right]$-Etn metabolite release from PNT2C2 and PNT1A over the 6-h time course (Figure 1). TPA had no significant effect on Etn metabolite release from P4E6 and LNCaP cells for the first $3 \mathrm{~h}$ of the 6 -h time course and, for LNCaP cells not even after $6 \mathrm{~h}$. PC3 cells showed the most significant increase in $\left[{ }^{3} \mathrm{H}\right]$-Etn metabolite release in response to TPA, stimulation being most marked over the first $3 \mathrm{~h}$ (Figure 1). These effects are reflected in the 3-h TPA stimulated/basal ratio of 1.5:1.3:1.09:0.94:2.2 for PNT2C2:PNT1A:P4E6:LNCaP:PC3 cell lines, respectively. In repeat experiments at $3 \mathrm{~h}, \mathrm{PC} 3$ cells routinely showed the highest TPA:basal stimulation ratio (2.1-3.5-fold) compared with PNT2C2 (1.8-2.2) and PNT1A cells (1.5-2.4). P4E6 and LNCaP cell lines showed no reproducible increase in Etn metabolite release in response to TPA in repeat 3-h stimulations (Figure 1, Figure 2A and B). Phorbol ester-stimulated Etn metabolite release by PNT2C2, PNT1A and PC3 cell lines was inhibited by Ro31-8220, GF109203X (Figure 2A) and D609 (Figure 2B).

Table 1. Distribution of $\left[{ }^{3} \mathrm{H}\right]$-label between PtdEtn and PtdCho after labelling prostate epithelial cell lines with $\left[1-{ }^{3} \mathrm{H}\right]$-ethanolamine for $36 \mathrm{~h}$

\begin{tabular}{|l|c|c|c|c|}
\hline Cell line & $\begin{array}{c}\text { PtdEtn } \\
\text { d.p.m. }+/- \text { s.d. }\end{array}$ & $\begin{array}{c}\text { PtdCho } \\
\text { d.p.m. }+/- \text { s.d. }\end{array}$ & $\begin{array}{c}\%\left[1-{ }^{3} \mathrm{H}\right] \\
\text { PtdEtn }\end{array}$ & $\begin{array}{c}\%\left[1-{ }^{3} \mathrm{H}\right] \\
\text { PtdCho }\end{array}$ \\
\hline PNT2C2 & $99666+/-1196$ & $3355+/-332$ & 96.7 & 3.3 \\
\hline PNT1A & $124201+/-10205$ & $4726+/-631$ & 96.3 & 3.7 \\
\hline P4E6 & $23464+/-4977$ & $1569+/-85$ & 93.3 & 6.7 \\
\hline LNCaP & $69166+/-2095$ & $3997+/-495$ & 94.5 & 5.5 \\
\hline PC3 & $16221+/-7141$ & $1060+/-511$ & 93.9 & 6.1 \\
\hline
\end{tabular}

Abbreviations: d.p.m. $=$ disintegrations per minute; $\mathrm{PtdEtn}=$ phosphatidylethanolamine PtdCho $=$ phosphatidylcholine; s.d. $=$ standard deviation. Results are means values of triplicate TLC separations as described in Methods and are $+/-$ s.d. $(n=3)$.

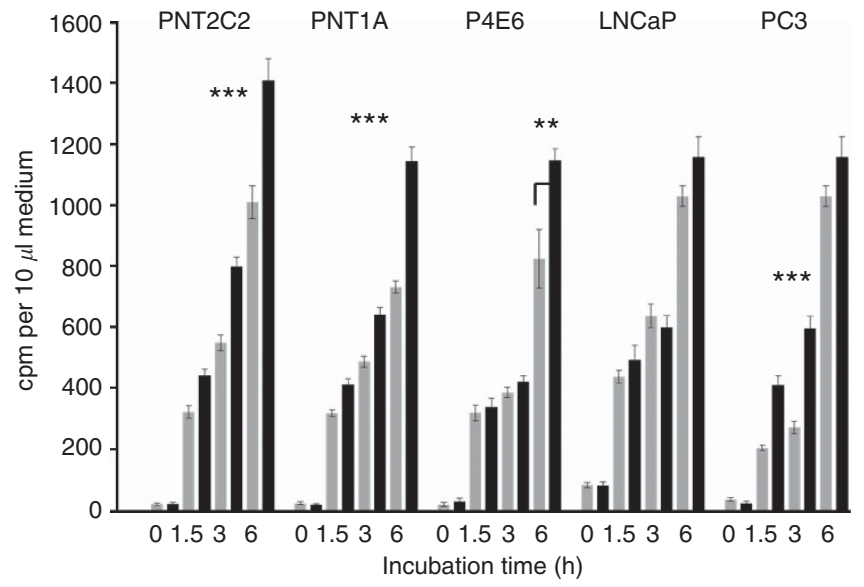

Figure 1. Effect of phorbol ester on Etn metabolite release by benign and cancer-derived human prostate epithelial cell lines. Cells were labelled with $\left[1-{ }^{3} \mathrm{H}\right]$-Etn as described in Methods. After rinsing, cells were incubated with serum-free basal medium $(\square)$ or with basal medium containing $1 \mu \mathrm{M}$ TPA ( $\mathbf{\square})$. [ $\left.{ }^{3} \mathrm{H}\right]$-Etn metabolite release to the medium was measured at time zero and after 1.5, 3 and $6 \mathrm{~h}$. Results are means $+/-$ s.d. $(n=6)$ and are typical of repeats. ( $* \star * P<0.0001$, $\star \star P<0.001$ for phorbol ester stimulation against basal). 

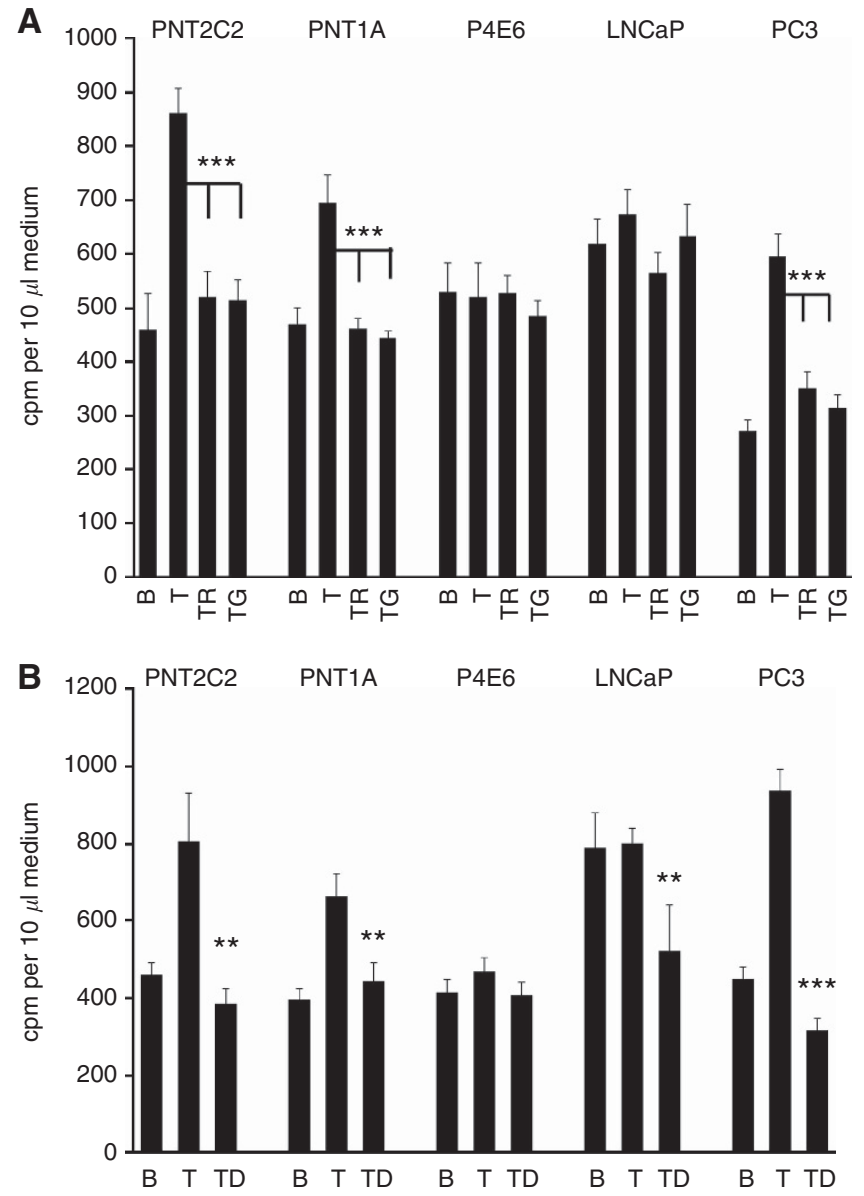

Figure 2. (A). Ro31-8220 and GF109203X inhibit phorbol esterstimulated release of Etn metabolites from human prostate epithelial cell lines. Cells were cultured and labelled with $\left[1-{ }^{3} \mathrm{H}\right]$-Etn as described (Methods). After rinsing, cells were incubated for $3 \mathrm{~h}$ with appropriate serum-free basal (B) medium (+ DMSO vehicle) or basal medium containing $1 \mu \mathrm{m}$ TPA (T), TPA $+1 \mu \mathrm{m}$ Ro31-8220 (TR) or TPA $+1 \mu \mathrm{m}$ GF109203X (TG). Results are means $+/-$ s.d. $(n=6)$ and are typical of repeats. *** $P<0.0001$ for inhibitor effects against TPA stimulated release. (B). Effect of D609 on TPA-stimulated release of [ $\left.{ }^{3} \mathrm{H}\right]$-labelled Etn metabolites by prostate epithelial cell lines. Cells were seeded, labelled and rinsed as described (Methods). After rinsing, cells were incubated for $3 \mathrm{~h}$ with appropriate serum-free basal (B) medium (+ DMSO vehicle) or basal medium containing $1 \mu \mathrm{M}$ TPA (T) or TPA $+100 \mu \mathrm{m}$ D609 (TD). Results are mean values $+/-$ s.d. $(n=6)$. $\star \star * P<0.0001$ and ${ }^{* \star} P<0.001$ for inhibitor effects against TPA stimulated release.

D609 reduces TPA-stimulated PLD activity in a transphosphatidylation reaction. D609 at $100 \mu \mathrm{M}$ and $200 \mu \mathrm{M}$ significantly inhibited TPA-stimulated PtdBut formation by PC3 cells in the transphosphatidylation reaction indicative of an effect on PLD (Morris et al, 1997). TPA-stimulated PtdBut formation was also inhibited by $1 \mu \mathrm{M}$ GF109203X (Figure 3). D609 at $100 \mu \mathrm{M}$ had no inhibitory effect on basal PtdBut formation.

Etn metabolites released by cell lines. Unstimulated cell lines released $\left[{ }^{3} \mathrm{H}\right]$-Etn metabolites to the medium in the order Etn $>$ GPEtn $>>$ PEtn (Figure 4). This order was unchanged when PNT2C2 and PNT1A were stimulated with TPA (Figure 4) even though total $\left[{ }^{3} \mathrm{H}\right]$-Etn metabolite release was increased (Figure 1). In contrast, TPA treatment of PC3 cells both increased total $\left[{ }^{3} \mathrm{H}\right]-$ Etn metabolite (Figure 1) and Etn release at the expense of GPEtn and PEtn (Figure 4).

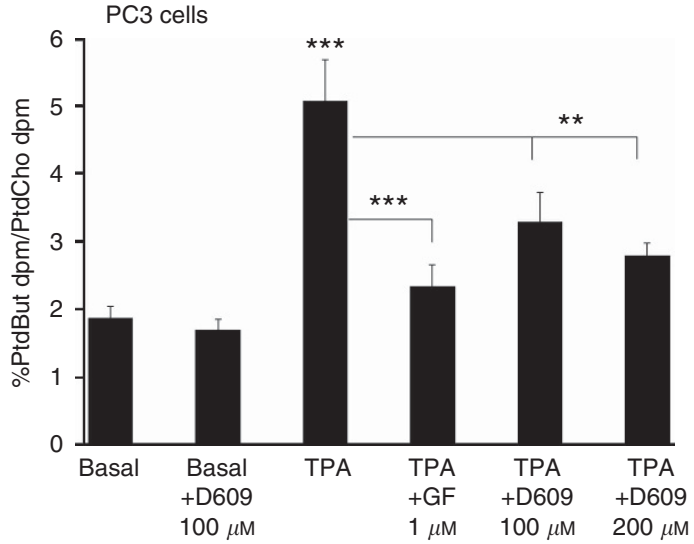

Figure 3. D609 inhibits phorbol ester-stimulated PtdBut formation by PC3 cells in the transphosphatidylation reaction. PC3 cells were labelled for $6 \mathrm{~h}$ with $\left[{ }^{3} \mathrm{H}\right]$-myristate, rinsed in serum-free medium and stimulated with TPA, TPA + $1 \mu \mathrm{m}$ GF109203X (TPA + GF) or TPA + D609 at $100 \mu \mathrm{M}$ and $200 \mu \mathrm{m}$ in the presence of $0.3 \% \mathrm{n}$-butanol. After $60 \mathrm{~min}$, cells were rinsed, extracted and PtdBut, PtdOH and PtdCho resolved as described in Methods. Results are \% PtdBut d.p.m. / PtdCho d.p.m. and are mean values $+/-$ s.d. $(n=3)$. For PtdBut formation, TPA against basal and GF against TPA ${ }^{\star \star \star} P<0.0001$; for D609 against TPA ${ }^{\star \star} P<0.001$.

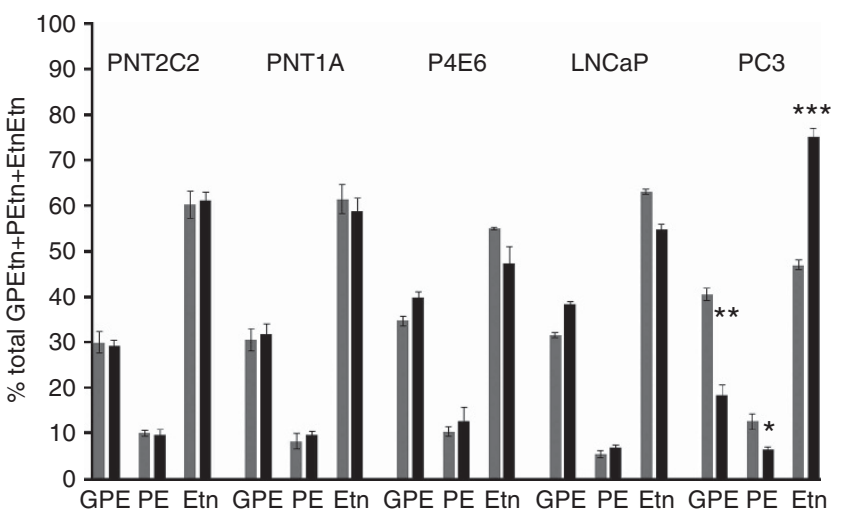

Figure 4. Metastatic PC3 cells upregulate Etn release on phorbol ester treatment. Cells were cultured and labelled with [1- $\left.{ }^{3} \mathrm{H}\right]$-Etn (Methods). After rinsing, cells were incubated for $3 \mathrm{~h}$ with serum-free basal $(\square)$ medium (+DMSO) or basal medium containing $1 \mu \mathrm{M}$ TPA (ם) Media were recovered and GPEtn, PEtn and Etn resolved by ion-exchange chromatography (Methods). Total d.p.m. associated with each fraction were calculated and results for each metabolite expressed as \% of total GPEtn + PEtn + Etn d.p.m. Results shown are mean values +/ - s.d. $(n=3)$ from a typical experiment. For PC3 cells, GPE, basal against TPA $\star \star P=0.005 ; P E$, basal against TPA, ${ }^{\star} P=0.04$; Etn, basal against TPA $\star \star * P=0.0003$.

Phorbol ester stimulates Etn metabolite release in the presence of serum. PNT2C2 cells were used to determine whether activation of PKC by TPA enhanced Etn metabolite release from cells already stimulated by serum. R10 medium (10\% serum) increased basal Etn metabolite release by $1.3 \%(537+/-27$ to $688+/-42$ c.p.m. $/ 10 \mu \mathrm{l}$ medium) over a 3-h incubation. Addition of $1 \mu \mathrm{M} \mathrm{TPA}$ to R10 medium boosted Etn metabolite release by $2.8 \%$ (537 $+/-27$ to $1484+/-61$ c.p.m./10 $\mu \mathrm{l}$ medium).

Oleate stimulates Etn metabolite release. Oleate (1 mM) activates PLD2 in cultured mast cells (Sarri et al, 2003). Therefore, this agent was used to examine whether PLD2 was involved in PtdEtn turnover (Figure 5). In initial 60-min experiments, PNT2C2 and 


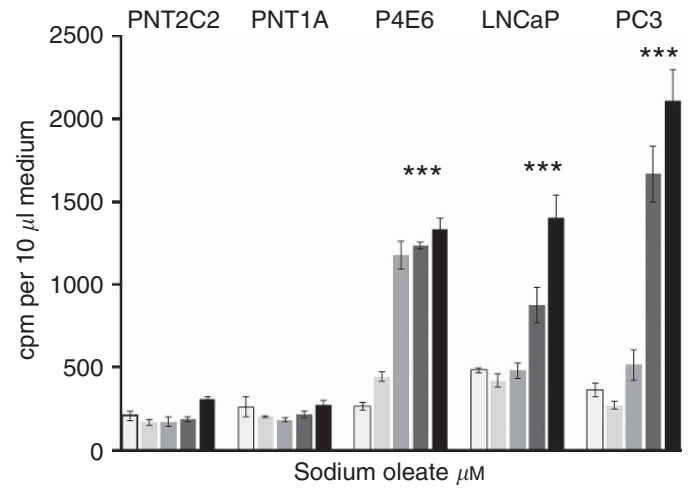

Figure 5. Etn metabolite release from prostate epithelial cell lines in response to varying $\mathrm{NaOL}$ concentrations. Cells were labelled with $\left[1-{ }^{3} \mathrm{H}\right]-$ Etn as described in Methods. After rinsing, cells were incubated at $37^{\circ} \mathrm{C}$ in fresh medium containing $0(\square), 250(\square), 500(\square), 750(\square)$ or $1 \mathrm{~mm} \mathrm{NaOL}(\boldsymbol{\square})$ prepared as described. After an hour, $10 \mu \mathrm{l}$ aliquots of medium were removed for scintillation counting (Methods). Results are means $+/-$ s.d. $(n=6)$. ${ }^{* \star \star} P<0.0001$ for $\mathrm{NaOL}$ effects against basal.

PNT1A cells were relatively unresponsive to oleate compared with tumorigenic cell lines. P4E6 cells especially showed a rapid release of Etn metabolites in response to oleate even at $500 \mu \mathrm{M}$ (Figure 5). In 3 -h time course experiments, $1 \mathrm{~mm}$ oleate stimulated Etn metabolite release from PNT2C2, P4E6 and PC3 cell lines in a time-dependent manner (Figure 6A-C). Again, P4E6 cells responded more rapidly to oleate (Figure $6 \mathrm{~B}$ ) than the other cell lines. The oleate effect was not inhibited by $1 \mu \mathrm{M}$ GF109203X (Figure 6A-C) and only partially by $100 \mu \mathrm{M}$ D609 (results not shown). GlycerylphosphorylEtn and PEtn were the main metabolites released from the three cell lines after oleate stimulation, in all cases at the expense of Etn (Figure 7A-C).

Mastoparan stimulates Etn metabolite release. The cationic tetradecapeptide mastoparan selectively activates PLD2 in intact cells (Chahdi et al, 2003) and at $5 \mu \mathrm{M}$ and $15 \mu \mathrm{M}$ concentrations stimulated $\left[{ }^{3} \mathrm{H}\right]$-Etn metabolite release from PNT2C2, P4E6 and PC3 cell lines (Figure 8A-C). GlycerylphosphorylEtn and PEtn were the main metabolites released from tumorigenic cell lines P4E6 and PC3 at the expense of Etn. Treatment of benign-derived PNT2C2 cells with mastoparan upregulated total Etn metabolite release (Figure $8 \mathrm{~A}$ ) but Etn metabolites were released in the same ratio as from unstimulated cells.

Mastoparan but not sodium oleate stimulates PtdBut formation. Incubation of PNT2C2 cells with $1 \mathrm{~mm} \mathrm{NaOL}$ and n-butanol for 30 min did not stimulate PtdBut formation in the transphosphatidylation reaction. In a typical experiment basal PtdBut formation expressed as \% d.p.m. PtdBut/d.p.m. PtdCho was 3.22\% $+/-1.01$ (mean $+/-$ s.d., $n=6$ ) whereas with sodium oleate stimulation the mean figure was $2.50+/-0.28$ (s.d., $n=5$ ). For TPA-stimulated cells the PtdBut figure was $5.77 \%+/-0.55$ over basal (see Figure 3). In duplicate experiments, mastoparan-7 stimulated PtdBut formation 1.33/1.7 times over basal in PNT2C2 cells, 2.8/2.6 times in P4E6 cells and 4.7/3.6 times in PC3 cells. Inactive M17 had no effect on PtdBut formation in any cell line.

Ionomycin stimulates GPEtn release. Ionomycin at $2.5 \mu \mathrm{M}$ but not at $1 \mu \mathrm{M}$ stimulated a rapid release of Etn metabolites from PNT2C2 cells relative to basal (Figure 9A), an effect not observed with the PC3 cell line (Figure 9B). Ionomycin increased GPEtn release from PNT2C2 cells at the expense of Etn (Figure 9C) but had little effect on the ratio of Etn metabolites released from PC3 cells (Figure 9D).

Etn does not stimulate LNCaP or PC3 cell proliferation but inhibits Cho uptake. Etn at 20,50 and $100 \mu \mathrm{M}$ did not stimulate
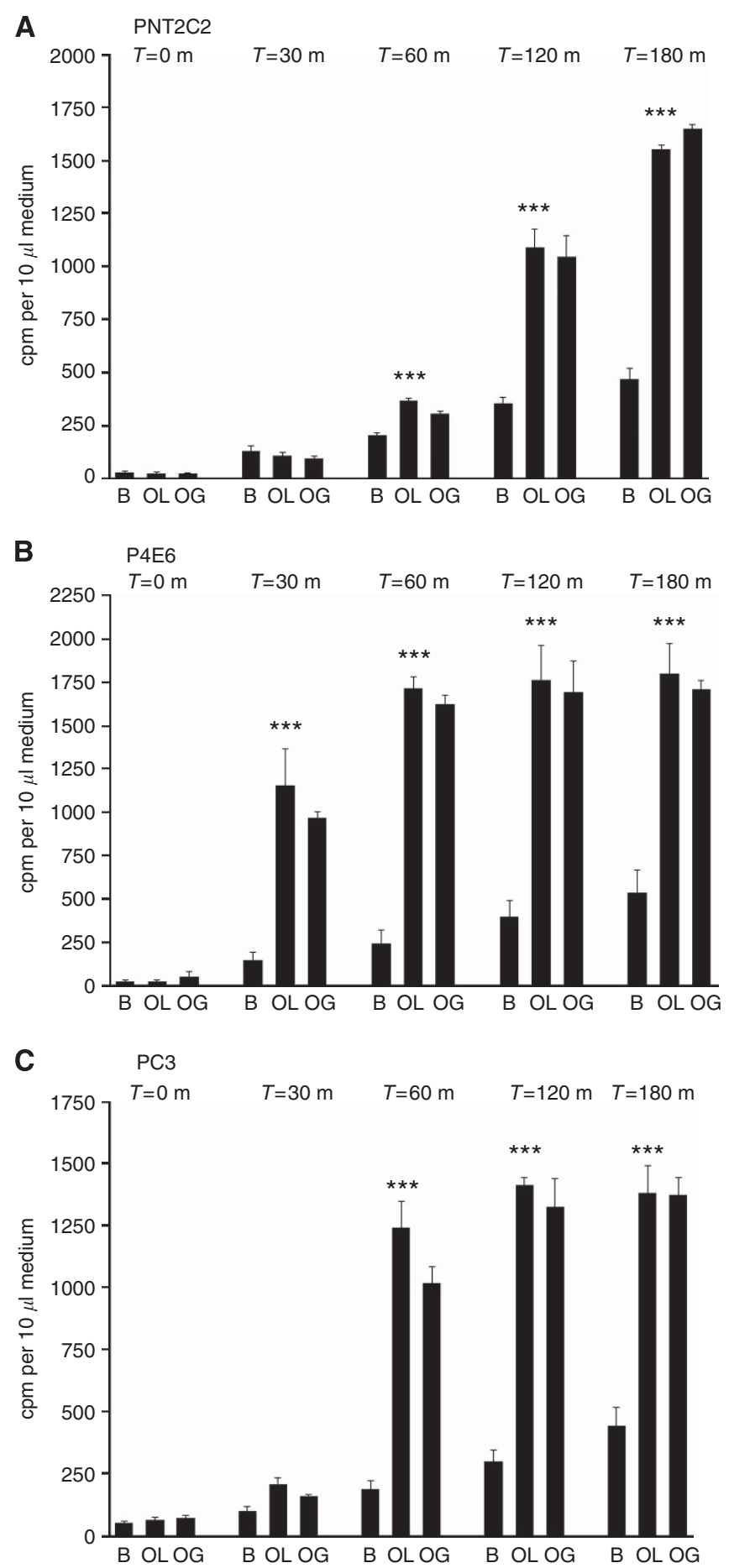

Figure 6. (A-C). Effect of $1 \mathrm{~mm}$ sodium oleate $(\mathrm{OL})$ and oleate $+1 \mu \mathrm{m}$ GF109203X (OG) on Etn metabolite release from PNT2C2, P4E6 and PC3 cell lines. Cells were labelled with $\left[1-{ }^{3} \mathrm{H}\right]$-Etn as described in Methods. After rinsing, cells were incubated at $37^{\circ} \mathrm{C}$ in fresh medium containing $1 \mathrm{~mm} \mathrm{NaOL}$. Aliquots of medium were removed for scintillation counting (Methods) at the times shown. Results are mean $+/-$ s.d. $(n=6)$ for a typical experiment from two repeats. For $(\mathbf{A}-\mathbf{C})$, $\star \star \star P<0.0001$ for $\mathrm{NaOL}$ effects against basal.

LNCaP or PC3 cell proliferation in a 48-h MTS assay (Figure 10A). In the same system, EGF at 20 and $50 \mathrm{ng} \mathrm{ml}^{-1}$ stimulated LNCaP cell proliferation but not that of $\mathrm{PC} 3$ cells, which are unresponsive to this growth factor (El Sheikh et al, 2004). However, Etn did not synergise with EGF to further enhance LNCaP cell proliferation. In the Click-iT EdU assay, treatment of LNCaP cells with R10 

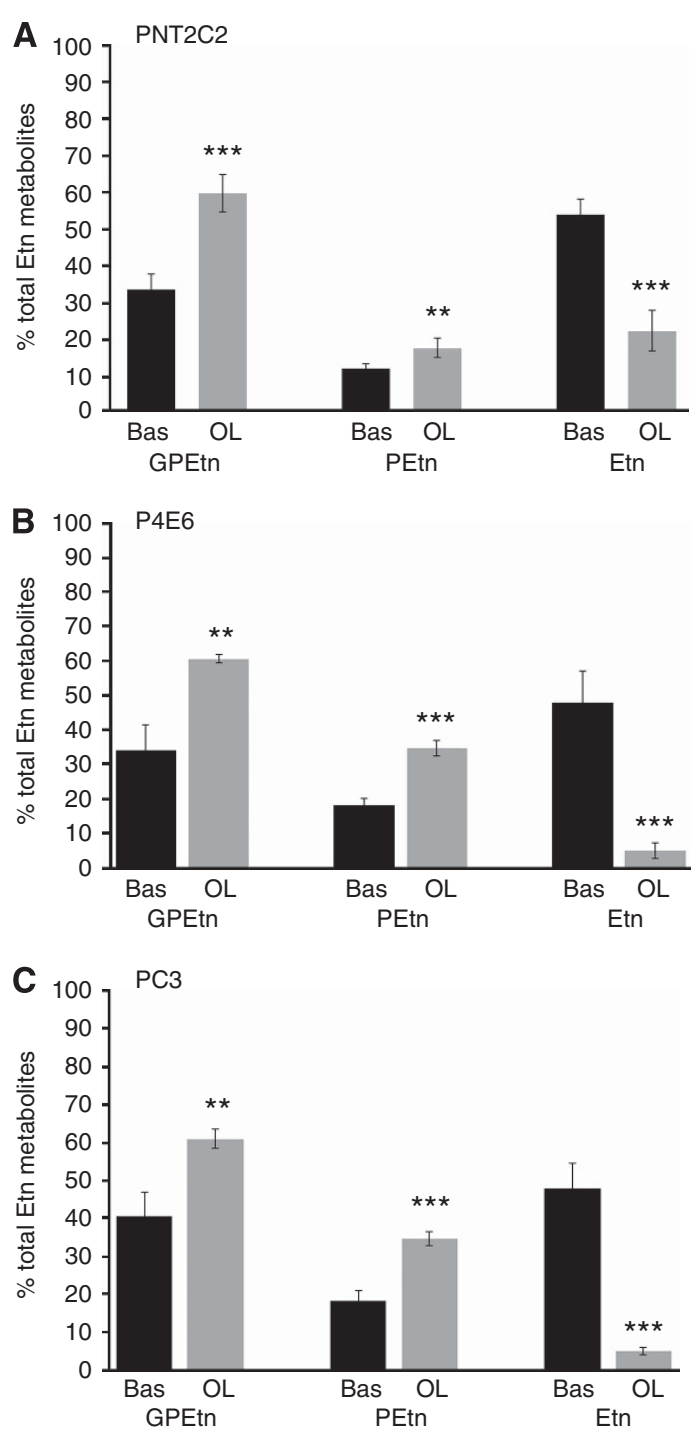

Figure 7. (A-C). Oleate decreases Etn release from PNT2C2, P4E6 and PC3 cell lines and increases GPEtn and PEtn release. Etn metabolites in media from 3-h time course experiments were resolved by ion-exchange chromatography as described in Methods. Total d.p.m. for each metabolite was calculated and individual metabolites expressed as a \% of GPEtn + PEtn + Etn. Results are mean values + / - s.d. $(n=6)$ from duplicate media analyses. OL against basal values, (A), ${ }^{*} \star \star P<0.0001$, ${ }^{\star \star} P<0.001 ;(\mathbf{B}){ }^{\star \star} P=0.0002,{ }^{\star \star \star} P P<0.0001 ;(\mathbf{C}),{ }^{\star \star} P=0.006$, ${ }^{\star \star \star} P<0.0001$.

medium and PC3 cells with F7 medium for $48 \mathrm{~h}$ increased the \% of green nuclei relative to total nuclei from $3.8+/-1.98$ to $20.97+/$ -1.99 and $3.8+/-1.198$ to $23.7+/-2.8$, respectively (results $+/-$ s.d., $n=3$ ). Etn at 10,20 and $50 \mu \mathrm{M}$ had no significant proliferative effect on either LNCaP or PC3 cells. EGF at $10 \mathrm{ng} \mathrm{ml}^{-1}$ increased the $\%$ of green relative to total nuclei from $3.8+/-1.64 \%$ to $10.1+/-3.0 \%$ (results $+/-$ s.d., $n=3$ ) in LNCaP cells but had no effect on PC3 cells, in agreement with the MTS results above. Etn at a concentration of $2.5 \mu \mathrm{M}$ and higher in culture medium, which is normally Etn-free, reduces $\left[{ }^{3} \mathrm{H}\right]-\mathrm{Cho}$ uptake into PC3 cells by about 20\% (Figure 10B).

\section{DISCUSSION}

Basal Etn metabolite release. The time-dependent release of $\left[{ }^{3} \mathrm{H}\right]$-Etn metabolites to the medium (Figure 1) by all unstimulated cell lines reflects the normal basal turnover of EtnPGs concentrated in the cytosolic leaflet of cell membranes (e.g., Vance 2008). None of the cell lines significantly methylated PtdEtn to PtdCho (Table 1) in keeping with findings that PtdEtn methylation pathways are mainly active in hepatocytes (Vance et al, 2007; Vance and Ridgway 1988). Hence, we can be confident that $\left[{ }^{3} \mathrm{H}\right]$ label released to the medium by cells is derived from turnover of EtnPGs. Etn is the major metabolite released (Figure 4) by cell lines. Phospholipase D is not generally involved in the basal turnover of phospholipids (Hii et al, 1991). However, in unstimulated LNCaP and PC3 cells, some basal PLD activity could contribute to Etn release because D609 reduced TPA-stimulated Etn metabolite release to below basal values (Figure 2B). D609 inhibits PLD in PC3 cells because we show that it blocks the PLDspecific transphosphatidylation reaction (Figure 3) in agreement with its effect on PLD in fibroblasts (Kiss and Tomono, 1995). D609 may inhibit PtdCho-PLC, PLA 2 and sphingomyelin synthase in other cell systems (Muller-Decker, 1989; van Dijk et al, 1997; Luberto and Hannun, 1998; Kang et al, 2008), but none of these enzymes release Etn directly from EtnPGs. Basal EtnPG turnover in the cell lines is not linked to PKC because neither Ro31-8220 nor GF109203X inhibit TPA-stimulated Etn metabolite release to below basal levels (Figure 2A). Further, GF109203X does not reduce TPA-stimulated PLD activity to below basal values in the transphosphatidylation reaction (Figure 3). Ro31-8220 and GF109203X are widely used PKC inhibitors (Gordge and Ryves 1994). Both inhibit several kinases (Alessi, 1997), but of these, only PKC is linked to activation of PLD1, and possibly PLD2 (Chen and Exton, 2004).

Basal Etn release could involve an N-acylPtdEtn-PLD (NAPEPLD), N-acylethanolamide (NAE), N-acylEtn-hydrolysing acid amidase (NAAA) and/or fatty acid amide hydrolase (FAAH) pathway (Ueda et al, 2010; Coulon et al, 2012). N-acylPtdEtn is a minor prostate cell phospholipid, but its levels and that of NAE are elevated in prostate tumours (Schmid et al, 2002). mRNA and protein for NAAA, NAPE-PLD and FAAH are variously detected in normal and transformed prostate epithelial cells and cell lines and PCa tissue (Endsley et al, 2008; Wang et al, 2008). This pathway is relevant to PCa because NAEs generated by NAPEPLD, especially anandamide (20:4 NAE), are endogenous cannabinoid receptor agonists and levels of cannabinoid receptors are elevated in PCa cells (Sarfaraz et al, 2005). Stimulation of cannabinoid receptors in LNCaP cells inhibits cell growth (Sarfaraz et al, 2005) and induces apoptosis (Sarfaraz et al, 2006). The antiproliferative effects of $n-3$ polyunsaturated fatty acids on cancer cells (Berquin et al, 2008) may be partly due to their conversion to NAE derivatives (Balvers et al, 2010; Brown et al, 2011) which then act on the cannabinoid receptors (de Petrocellis et al, 1998; Mimeault et al 2003; Brown et al, 2010).

Basal release of GPEtn by all cell lines suggests the involvement of a PLA $\mathrm{PL}_{2}$ with lysophospholipase activity such as $\mathrm{CPLA}_{2} \alpha$ (Ghosh et al, 2006), which is active in PC3 cells (Patel et al, 2008). PhosphorylEtn is the minor Etn metabolite released by all cell lines on basal EtnGP turnover perhaps because high intracellular PEtn levels are maintained for the rate-limiting CTP:phosphoEtn cytidylyltransferase reaction in EtnGP biosynthesis (Vance 2008). This would agree with spectroscopic results that PEtn is the major metabolite detected in intact benign and malignant prostate tissue (Swanson et al, 2008; Komoroski et al, 2011).

Phorbol ester-stimulated Etn metabolite release. Only the PC3 cell line used as a model of androgen-independent refractory stage PCa increased Etn release at the expense of GPEtn and PEtn on TPA treatment; this effect was not observed in LNCaP cells used to model androgen-sensitive disease. Taking the inhibitory effects of Ro318220, GF109203X and D609 into account, the most plausible explanation for this result is that a PKC-PLD1 pathway hydrolysing 

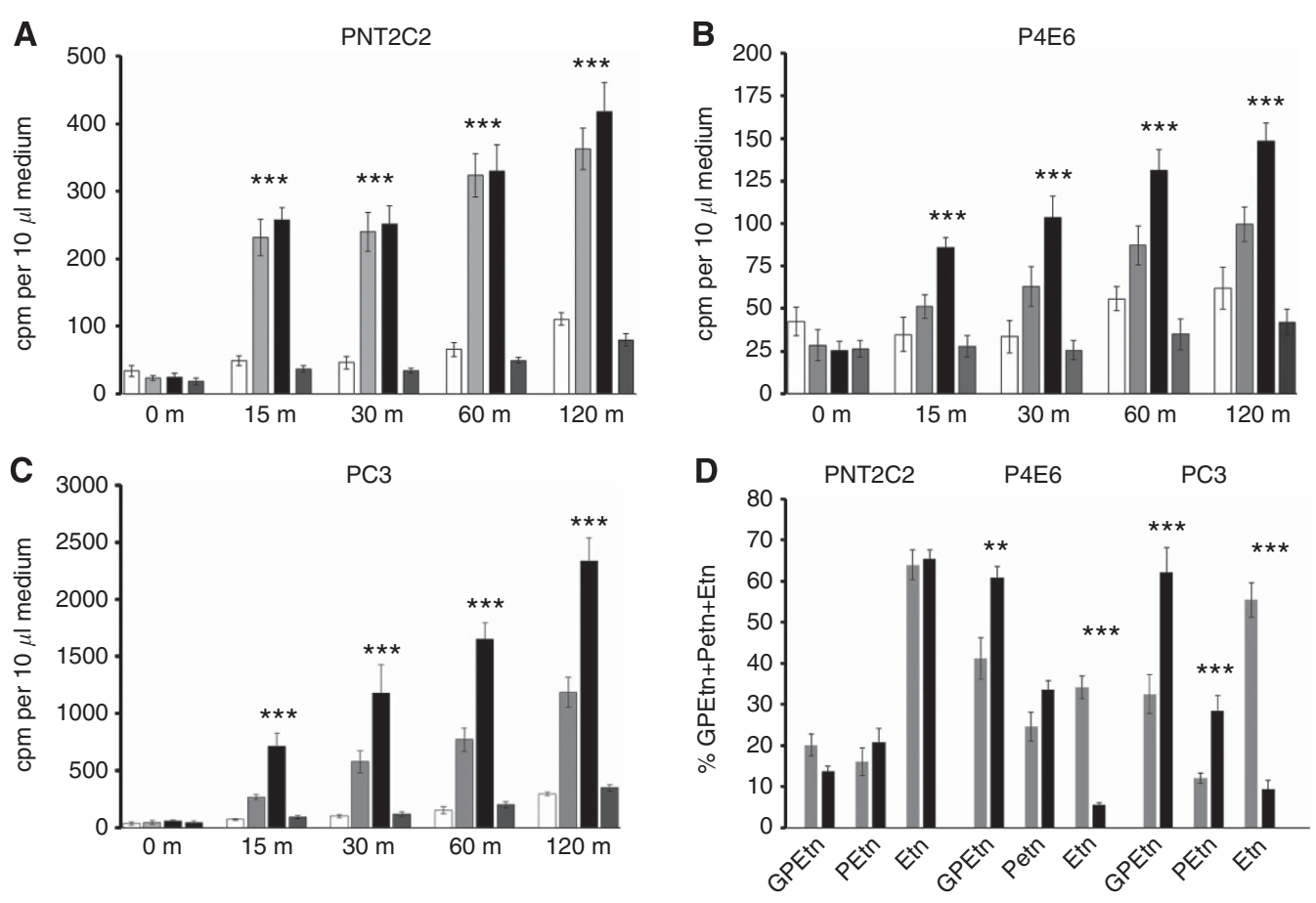

Figure 8. (A-C). Mastoparan-7 stimulates Etn metabolite release from PNT2C2, P4E6 and PC3 cell lines, and D, increases GPEtn and PEtn release from P4E6 and PC3 cell lines at the expense of Etn. Cells were labelled with $\left(1-{ }^{3} \mathrm{H}\right)$-Etn as described in Methods. After rinsing, cells were incubated at $37^{\circ} \mathrm{C}$ in fresh medium containing $0(\square), 5(\square)$ and $15 \mu \mathrm{M}(\square)$ mastoparan-7 or $15 \mu \mathrm{m}$ inactive mastoparan 17 ( $\square$ ). Aliquots of medium were removed at the time intervals shown for scintillation counting (Methods). In (D), Etn metabolites were resolved by ion-exchange chromatography (Methods). In (A-C), Mastoparan $7(15 \mu \mathrm{M})$ against basal, ${ }^{\star \star \star} P<0.0001$. In (D), mastoparan-7 against basal, ${ }^{\star \star} P<0.001,{ }^{\star \star \star} P<0.0001$.
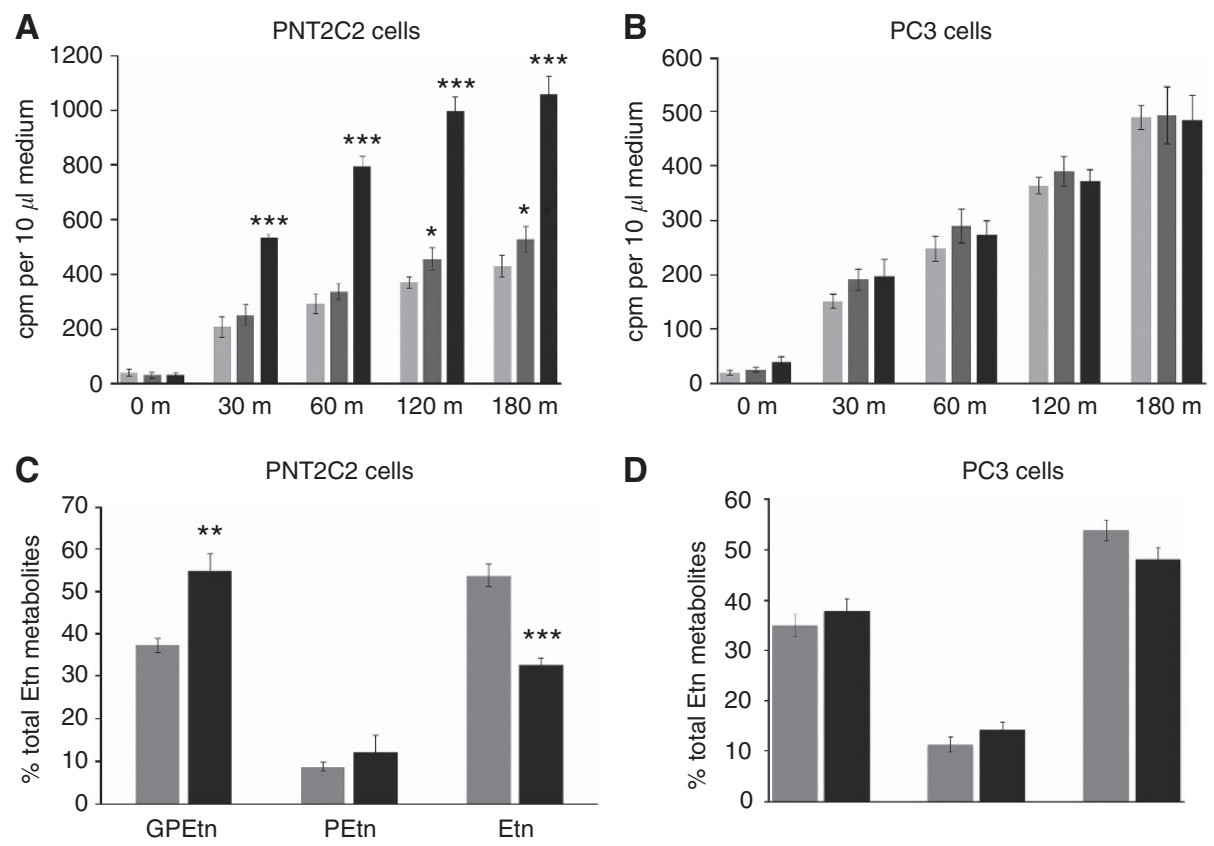

Figure 9. (A, B). lonomycin promotes Etn metabolite release from PNT2C2 (A) but not from PC3 (B) prostate cell lines. (C, D). lonomycin stimulates GPEtn release from the benign PNT2C2 but not from the metastatic PC3 cell line. Cells were labelled with [1- $\left.{ }^{3} \mathrm{H}\right]-\mathrm{Etn}$ as described in Methods. After rinsing, cells were incubated at $37^{\circ} \mathrm{C}$ in basal medium containing DMSO vehicle $(\square)$ or $1(\square)$ or $2.5 \mu \mathrm{m}(\mathbf{\square})$ ionomycin. Aliquots of medium were removed at the time intervals shown for scintillation counting. Results are mean d.p.m./10 $\mu$ l medium and are $+/-$ s.d. ( $n=6)$. In (C and D), Etn metabolites in media from basal- $(\square)$ and ionomycin- ( $\square$ ) treated cells were resolved by ion-exchange chromatography (Methods). Results are presented as in the legend for Figure 4. In A, ionomycin against basal ${ }^{\star \star \star} P<0.0001$. In (C), ionomycin against basal ${ }^{\star \star} P<0.001$, $\star \star \star P<0.0001$.

EtnPGs is activated in this cell line and not in the other cell lines examined (McDermott et al, 2004). Basally active PLD2 may also be involved, but its regulation by PKC is not fully resolved (e.g., Han et al, 2002; Chen and Exton 2004; Gomez-Cambronero 2011). Phosphatidylcholine is usually regarded as the main substrate for PLD1 (Pettitt et al, 2001; Jenkins and Frohman 2005), but our 

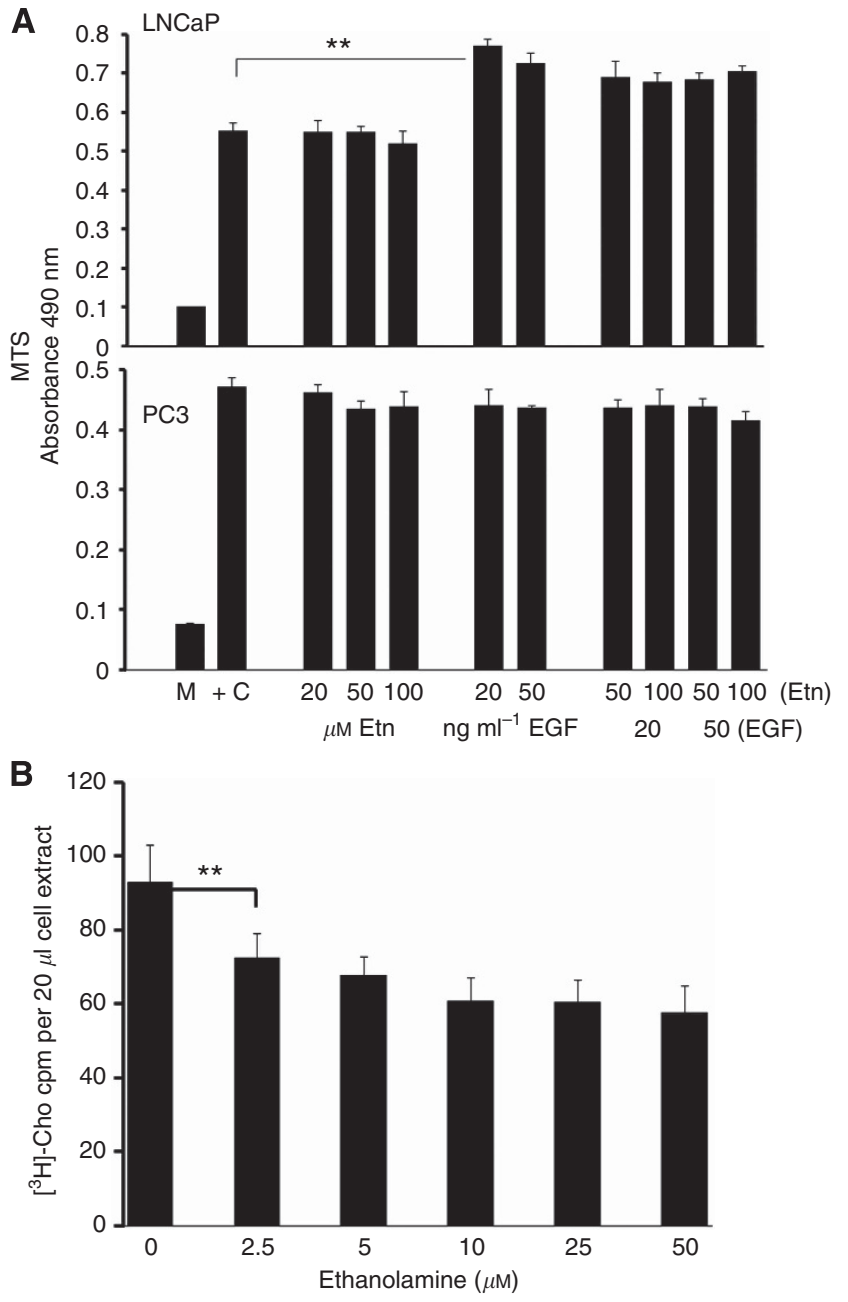

Figure 10. (A) Etn does not stimulate LNCaP or PC3 cell proliferation. Cells in serum-free medium were treated as shown with Etn, EGF or $\mathrm{EGF}+$ Etn for $48 \mathrm{~h}$ and cell proliferation measured in an MTS assay. Results are mean MTS absorbance values $+/-$ s.d $(n=6)$, ${ }^{\star} P<0.001$ for EGF against basal. (B) Etn reduces $\left[{ }^{3} \mathrm{H}\right]$-Cho uptake into PC3 cells. PC3 cells were incubated in Hank's balanced salt solution containing different concentrations of Etn as described in Methods. Results shown are Etn effects on $\left[{ }^{3} \mathrm{H}\right]$-Cho uptake after $3 \mathrm{~min}$ and are the mean of replicates $+/-$ s.d. $(n=3)$. ${ }^{\star \star} P<0.001$ for $2.5 \mu \mathrm{M}$ Etn against zero Etn.

findings indicate that PtdEtn and/or PlasEtn species are additional PLD1 substrates in PC3 cells on PKC stimulation as in other mammalian cells (Singh et al, 2005; Kiss et al 1994; Kiss and Tomono 1995). However, in PC3 cells, PtdEtn/PlasEtn is not an exclusive PLD1 substrate as observed in MCF-7/MDR cells (Kiss et al, 1994) because Cho release also increases on TPA treatment (Rumsby et al, 2011). Phorbol ester increases total Etn metabolite release from benign PNT2C2 and PNT1A cells (Figure 1) as for Cho metabolites (Rumsby et al, 2011), but this appears to occur by an upregulation of basal mechanisms of EtnGP turnover because the GPEtn:PEtn:Etn ratio does not change (Figure 4).

Involvement of PLD2. Oleate at low mM concentrations activates PLD2 in intact mast cells (Sarri et al, 2003); hence, we tested whether it would stimulate EtnPG turnover in the PCa cell lines. Oleate certainly stimulated total Etn metabolite release, but this was not due to activation of PLD2 because release of Etn decreased relative to GPEtn and PEtn, and further, oleate did not stimulate PtdBut formation in the PLD-specific transphosphatidylation reaction. This result was surprising for PC3 cells, which express both PLD1 and PLD2 (Gibbs and Meier 2000). The increased formation of GPEtn by oleate suggests that a PLA 2 with lysoPA activity such as cPLA2 $\alpha$, which requires $\mathrm{Ca}^{2+}$, could have been activated (Ghosh et al, 2006). A rise in intracellular $\mathrm{Ca}^{2+}$ could be triggered by oleate action on L-type $\mathrm{Ca}^{2+}$ channels (e.g., Chang et al, 2000; Tian et al, 2009) expressed by LNCaP and PC3 cell lines (e.g., Huang et al, 2005; Sun et al, 2006; Gackiere et al, 2008) and/ or by oleate activation of the fatty acid receptor GPR40 expressed in PCa cell lines (Rumsby, unpublished), which is linked to a rise in intracellular $\mathrm{Ca}^{2+}$ (Hardy et al, 2005). Ionomycin increases GPEtn release at the expense of Etn from PNT2C2 cells supporting the idea that the observed oleate effect involves a rise in intracellular $\mathrm{Ca}^{2+}$. This was not observed with PC3 cells (Figure 9B and D) highlighting another difference between these prostate epithelial cell lines. Oleate treatment caused reversible cell rounding, which might also have allowed $\mathrm{Ca}^{2+}$ entry and $\mathrm{CPLA}_{2}$ activation. These results indicate that oleate does not activate PLD2 in prostate cell lines unlike its effects in mast cells (Sarri et al, 2003). The cationic tetradecapeptide mastoparan reportedly activates PLD2 in intact mast cells (Chahdi et al, 2003) and we found that it stimulated PtdBut formation in the PLD-specific transphosphatidylation reaction. However, it did not specifically stimulate PLD in P4E6 and PC3 cell lines because GPEtn and PEtn were the main metabolites released suggesting a preferential activation of $\mathrm{PLA}_{2}$ and PtdEtn-PLC as observed in other cell types (Argiolas and Pisano, 1983; Schnabel et al, 1997; Ferry et al, 2001). With benign PNT2C2 cells, mastoparan upregulated basal mechanisms of EtnGP turnover because Etn metabolites were released in the same ratio as from unstimulated cells.

Relevance to PCa. Upregulated protein expression of PKC $\alpha$ and increased signalling by growth factors such as EGF that activate PKC are features of PCa (Cornford et al, 1999; de Miguel et al, 1999; Koren et al, 2004; Lahn et al, 2004; Stewart and O’Brian, 2005). Such observations suggest that a PKC-PLD1 pathway may be upregulated in PCa cells as is observed for PLD in other cancer cells and transformed cell lines (Foster and $\mathrm{Xu}, 2003$ ). Androgendependent LNCaP and androgen-independent PC3 cell lines are widely used models of early and later stages of PCa, respectively, and our results suggest that these two cell lines differ in the regulation of PtdCho and EtnPG turnover by PKC as judged by the release of Cho and Etn metabolites. Androgen-independent PC3 cells appear to possess a PLD1 pathway that is upregulated on activation of PKC leading to increased turnover of both EtnPGs and PtdCho (Rumsby et al, 2011). This pathway and/or the ability to release Cho and Etn metabolites on PKC activation appears to be lacking in LNCaP cells. The extra PtdOH generated by the increased turnover of EtnPG in PC3 cells would maintain a cancer phenotype through mTOR (Foster, 2009; Toschi et al, 2009) in addition to that from PtdCho turnover by PLD1. It would also increase signalling through $\mathrm{PtdOH}$ (Wang et al, 2006) by promoting the membrane association of $\mathrm{PtdOH}$-binding proteins (Stace and Ktistakis, 2006) including PI4P 5-kinase, which generates PI(4,5)P2 essential for PLD activity (Jenkins and Frohman, 2005) and Raf-1 kinase and sphingosine kinase 1, both regulators of proliferation and apoptosis (e.g., Rizzo et al, 2000; Spiegel and Milstien 2002). Phosphatidic acid is also implicated in cell motility associated with metastasis (Mazie et al, 2006; Clarke et al 2009). Fatty acids in PtdOH derived from PtdEtn will be more unsaturated than those from PtdCho (Pettitt et al 1997; Weisser and Krieg 1998) while PtdOH from PlasEtn will contain 1-0-alkyl or 1-0-alkenyl chains. Such structural differences may result in EtnPG-derived PtdOH having different signalling, protein interaction, membrane fusion and fission properties, all linked to tumorigenesis (Jenkins and Frohman 2005; Wang et al, 2006). Phosphatidic acid is also readily converted by $\mathrm{PLA}_{2}$ to lysoPtdOH, 
an autocrine mediator in PCa cells (Daaka, 2002; Xie et al, 2002; Gibbs et al, 2009) promoting metastatic cell proliferation and motility.

Etn did not enhance PC3 cell growth as reported for other cell types (Kano-Sueoka et al, 1979; Murakami et al, 1982; Arthur and Lu, 1993; Kiss et al, 1997; Sasaki et al, 1997; Kume and Sasaki, 2006). However, at low concentrations, it did reduce Cho uptake as noted by others (e.g., Yorek et al, 1986; Lipton et al, 1988), hence it could modulate Cho uptake in vivo. Preferential uptake of Etn at the expense of Cho (Mintz et al, 2008) will increase EtnPG synthesis, regulating the membrane PtdCho:EtnPG ratio. This is tightly controlled because a deficiency of EtnPG causes abnormal PKC activity (Bazzi et al, 1992; Kano-Sueoka and Nicks, 1993) and impaired EGF binding to its receptor (Kano-Sueoka et al, 1990) as well as influencing the membrane association and function of PtdEtn-binding proteins, such as anti-apoptotic hPEBP4 (Li et al, 2007; Li et al, 2014) and Raf Kinase inhibitor protein, RKIP (Keller et al, 2005).

The use of spectroscopic methods to resolve phospholipid headgroup metabolites in the detection, diagnosis and characterisation of PCa (Kurhanewicz and Vigneron, 2008; DeFeo et al, 2011) and the suggestion that EtnPG metabolism may be a better marker for detection of PCa by spectroscopy than PtdCho (Komoroski et al, 2011) makes it important to understand how turnover of PtdCho and EtnPGs in PCa cells is regulated. Our results suggest that signalling pathways from PKC to PLD1 regulating turnover of PtdCho and EtnPGs differ in LNCaP and PC3 cell lines, two widely used models of early stage and later refractory stage PCa.

\section{ACKNOWLEDGEMENTS}

This research was funded by the Prostate Cancer Research Foundation (now Prostate Action), and Yorkshire Cancer Research. We thank Ms Ann Barker for excellent technical assistance.

\section{REFERENCES}

Aboagye EO, Bhujwalla ZM (1999) Malignant transformation alters membrane choline phospholipid metabolism of human mammary epithelial cells. Cancer Res 59: 80-84.

Ackerstaff E, Pflug BR, Nelson JB, Bhujwalla ZM (2001) Detection of increased choline compounds with proton magnetic resonance spectroscopy subsequent to malignant transformation of human prostatic epithelial cells. Cancer Res 61: 3599-3603.

Ackerstaff E, Glunde K, Bhujwalla ZM (2003) Choline phospholipid metabolism: A target in cancer cells? J Cell Biochem 90: 525-533.

Alessi D (1997) The protein kinase C inhibitors Ro318220 and GF $109203 \mathrm{X}$ are equally potent inhibitors of MAPKAP kinase- $1 \alpha($ Rsk-2) and p70S6 kinase. FEBS Lett 402: 121-123.

Argiolas A, Pisano J J (1983) Facilitation of phospholipase A2 activity by mastoparans, a new class of mast cell degranulating peptides from wasp venom. J Biol Chem 258(22): 13697-13702.

Arthur G, Lu X (1993) The ethanolamine requirement of keratinocytes for growth is not due to defective synthesis of ethanolamine phosphoacylglycerols by the decarboxylation pathway. Biochem J 293: $125-130$.

Balvers M G J, Verhoeckx K C M, Plastina P, Wortelboer H M, Meijerink J, Witkamp R F (2010) Docosahexaenoic acid and eicosapentaenoic acid are converted by 3T3-L1 adipocytes to $\mathrm{N}$-acylethanolamines with anti-inflammatory properties. Biochim Biophys Acta 1801: 1107-1114.

Bazzi M D, Youakim A Y, Nelsestuen G L (1992) Importance of phosphatidylethanolamine for association of protein kinase $\mathrm{C}$ and other cytoplasmic proteins with membranes. Biochemistry 31(4): $1125-1134$.

Bell JD, Bhakoo KK (1998) Metabolic changes underlying ${ }^{31} \mathrm{P}$ MR spectral alterations in human hepatic tumours. NMR Biomed 11: 354-359.
Berquin I M, Edwards I J, Chen Y Q (2008) Multi-targeted therapy of cancer by omega-3 fatty acids. Cancer Letts 269: 363-377.

Brown I, Cascio M G, Wahle K W J, Smoum R, Mechoulam R, Ross R A, Pertwee R G, Heys S D (2010) Cannabinoid receptor-dependent and independent anti-proliferative effects of omega- 3 ethanolamides in androgen receptor-positive and -negative prostate cancer cell lines. Carcinogenesis 31(9): 1584-1591.

Brown I, Wahle KW J, Cascio M G, Smoum-Jaouni R, Mechoulam R, Pertwee R G, Heys S D (2011) Omega-3 $N$-acylethanolamines are endogenously synthesised from omega-3 fatty acids in different human prostate and breast cancer cell lines. Prost Leuko Ess Fatty Acids 85: 305-310.

Caiazza F, McCarthy NS, Young L, Hill AD, Harvey BJ, Thomas W (2011) Cytosolic phospholipase A2-a expression is associated with EGFR exprression and correlates with an adverse prognosis in luminal tumours. Br J Cancer 104: 338-344.

Chahdi A, Choi WS, Kim YM, Beaven MA (2003) Mastoparan selectively activates phospholipase D2 in cell membranes. J Biol Chem 278: 12039-12045.

Chang CH, Chey WY, Chang TM (2000) Cellular mechanism of sodium oleate-stimulated secretion of cholecystokinin and secretin. Am J Physiol Gast Liver Physiol 279: G295-G303.

Chen J-S, Exton JH (2004) Regulation of phospholipase D2 activity by protein kinase C $\alpha$. J. Biol Chem 279: 22076-22083.

Clarke N W, Hart C A, Brown M D (2009) Molecular mechanisms of metastasis in prostate cancer. Asian J Androl 11: 57-67.

Cornford P, Evans J, Dodson A, Parsons K, Woolfenden A, Neoptolemos J, Foster CS (1999) Protein kinae C isoenzyme patterns characteristically modulated in early prostate cancer. Am J Pathol 154: 137-144.

Coulon D, Faure L, Salmon M, Wattelet V, Bessoule J-J (2012) Occurrence, biosynthesis and functions of $N$-acylphosphatidylethanolamines (NAPE): Not just precursors of $\mathrm{N}$-acylethanolamines (NAE). Biochimie 94: 75-85.

Daaka Y (2002) Mitogenic action of LPA in prostate. Biochim Biophys Acta 1582: $265-269$.

DeFeo E M, Wu C-L, McDougal W S, Cheng L L (2011) A decade in prostate cancer: from NMR to metabolomics. Nature Rev Urol 8: 301-311.

de Miguel P M, Royuela M, Bethencourt F R, Ruiz A, Fraile B, Paniagua R (1999) Immunohistochemical comparative analysis of transforming growth factor $\alpha$, epidermal growth factor and epidermal growth factor receptor in normal, hyperplastic and neoplastic human prostates. Cytokine 11: 722-727.

Dong Z, Liu Y, Scott KF, Levin L, Gaitonde K, Bracken RB, Burke B, Zhai QJ, Wang J, Oleksowicz L, Lu S (2010) Secretory phospholipase $A_{2}$-IIa is involved in prostate cancer progression and may potentially serve as a biomarker for prostate cancer. Carcinogenesis 31: 1948-1955.

El Sheikh SS, Domin J, Abel P, Stamp G, Lalani El-N (2004) Phosphorylation of both EGFR and ErbB2 is a reliable predictor of prostate cancer cell proliferation in response to EGF. Neoplasia 6: 846-853.

Eliyahu G, Kreizman T, Degani H (2007) Phosphocholine as a biomarker of breast cancer: molecular and biochemical studies. Int J Cancer 120: 1721-1730.

Endsley M P, Thill R, Choudhry I, Williams C L, Kajdacsy-Balla A, Campbell WB, Nithipatikom K (2008) Expression and function of fatty acid amide hydrolase in prostate cancer. Int J Cancer 123: 1318-1326.

Ferry X, Eichwald V, Daeffler L, Landry Y (2001) Activation of $\beta \gamma$ subunits of $G_{i 2}$ and $G_{i 3}$ proteins by basic secretagogues induces exocytosis through phospholipase $C \beta$ and arachidonate release through phospholipase $C \gamma$ in mast cells. J Immunol 167(9): 4805-4813.

Foster DA (2009) Phosphatidic acid signalling to mTOR: Signals for the survival of human cancer cells. Biochim Biophys Acta 1791: 949-955.

Foster DA, Xu L (2003) Phospholipase D in cell proliferation and cancer. Mol Cancer Res 1: 789-800.

Gackiere F, Bidaux G, Delcourt P, van Coppenolle F, Katsogiannou M, Dewailly E, Bavencoffe A, van Chuoi-Mariot MT, Mauroy B, Prevarskaya N, Mariot P (2008) $\mathrm{CaV}_{3.2}$ T-type calcium channels are involved in calciumdependent secretion of neuroendocrine prostate cancer cells. J Biol Chem 283: 10162-10173.

Ghosh M, Tucker DE, Burchett SA, Leslie CC (2006) Properties of the group IV phospholipase $\mathrm{A}_{2}$ family. Prog Lipid Res 45: 487-510.

Gibbs TC, Meier KE (2000) Expression and regulation of phospholipase D isoforms in mammalian cell lines. J Cell Physiol 182: 77-87.

Gibbs T C, Rubio M V, Zhang Z, Xie Y, Kipp K R, Meier K E (2009) Signal transduction responses to lysophosphatidic acid and sphingosine 1-phosphate in human prostate cancer cells. The Prostate 69: 1493-1506. 
Glunde K, Ackerstaff E, Mori N, Jacobs MA, Bhujwalla ZM (2006) Choline phospholipid metabolism in cancer: consequences for molecular pharmaceutical interventions. Mol Pharm 3: 496-506.

Gomez-Cambronero J (2011) The exquisite regulation of PLD2 by a wealth of interacting proteins: S6K, Grb2, Sos, WASp and Rac2 (And a surprise discovery: PLD2 is a GEF). Cell Signal 23: 1885-1895.

Gordge P C, Ryves W J (1994) Inhibitors of protein kinase C. Cell Signal 8: 871-882.

Han JM, Kim J H, Lee B D, Lee S D, Kim Y, Jung Y W, Lee S, Cho W, Ohba M, Kuroki T, Suh P-G, Ryu S H (2002) Phosphorylation-dependent regulation of phospholipase $\mathrm{D} 2$ by protein kinase $\mathrm{C} \delta$ in rat pheochromocytoma PC12 cells. J Biol Chem 277(10): 8290-8297.

Hardy S, St-Onge GG, Joly E, Langelier Y, Prfentki M (2005) Oleate promotes the proliferation of breast cancer cells via the $\mathrm{G}$ protein-coupled receptor GPR40. J Biol Chem 280: 13285-13291.

Herminghaus S, Pilatus U, Moller-Hartmann W, Raab P, Lanfermann H, Schlote W, Zanella FE (2002) Increased choline levels coincide with enhanced proliferative activity of human neuroepithelial tumors. NMR Biomed 15: 385-392.

Hii CST, Edwards YS, Murray AW (1991) Phorbol ester-stimulated hydrolysis of phosphatidylcholine and phosphatidylethanolamine by phospholipase D in HeLa cells. J Biol Chem 266: 20238-20243.

Huang JK, Liu CS, Chou CT, Liu SI, Hsu SS, Chang HT, Hsieh CH, Chang CH, Chen WC, Jan CR (2005) Effects of econazole on Ca2 + levels in and the growth of human prostate cancer PC3 cells. Clin Exp Pharmacol Physiol 32: 735-741.

Iorio E, Mezzanzanica D, Alberti P, Spadaro F, Ramoni C, D'Ascenzo S, Millimaggi D, Pavan A, Dolo V, Canevari S, Podo F (2005) Alterations of choline phospholipid metabolism in ovarian tumor progression. Cancer Res 65: 9369-9376.

Iorio E, Ricci A, Bagnoli M, Pisanu ME, Castellano G, Vito MD, Venturini E, Glunde K, Bhujwalla ZM, Mezzanzanica D, Canevari S, Podo F (2010) Activation of phosphatidylcholine cycle enzymes in human epithelial ovarian cancer cells. Cancer Res 70: 2126-2213.

Jenkins GM, Frohman MA (2005) Phospholipase D: a lipid centric review. CMLS Cell Mol Life Sci 62: 2305-2316.

Kang MS, Jung SY., Jung KM, Kim SK, Ahn KH, Kim DK (2008) D609, an inhibitor of phosphatidylcholine-specific phospholipase C, inhibits Group IV cytosolic phospholipase A2. Mol Cells 26: 481-485.

Kano-Sueoka T, Nicks ME (1993) Abnormal function of protein kinase C in cells having phosphatidylethanolamine-deficient and phosphatidylcholine excess membranes. Cell Growth Diff 4: 533-537.

Kano-Sueoka T, Cohen DM, Yamaizumi Z, Nishimura S, Mori M, Fujiki H (1979) Phosphoethanolamine as a growth factor of a mammary carcinoma cell line of rat. Proc Natl Acad Sci USA 76: 5741-5744.

Kano-Sueoka T, King DM, Fisk HA, Klug SJ (1990) Binding of epidermal growth factor to its receptor is affected by membrane phospholipid environment. J Cell Physiol 145: 543-548.

Katz-Brull R, Seger D, Rivenson-Segal D, Rushkin E, Degani H (2002) Metabolic markers of breast cancer: Enhanced choline metabolism and reduced choline-ether-phospholipid synthesis. Cancer Res 62: 1966-1970.

Keller E T, Fu Z, Brennan M (2005) The biology of a prostate cancer metastasis suppressor protein: Raf kinase inhibitor protein. J Cell Biochem 94: 273-278.

Kiss Z, Anderson WB (1989) Phorbol ester stimulates the hydrolysis of phosphatiodylethanolamine in leukemic HL-60, NIH 3T3 and baby hamster kidney cells. J Biol Chem 264: 1483-1487.

Kiss Z, Tomono M, Anderson WB (1994) Phorbol ester selectively stimulates the phospholipase D-mediated hydrolysis of phosphatidylethanolamine in multidrug-resistant MCF-7 human breast carcinoma cells. Biochem J 302: 649-654.

Kiss Z, Tomono M (1995) Compound D609 inhibits phorbol ester-stimulated phospholipase D activity and phospholipase $\mathrm{C}$ mediated phosphatidylethanolamine hydrolysis. Biochim Biophys Acta 1259: 105-108.

Kiss Z, Mukherjee J J, Crilly KS, Chung T (1997) Ethanolamine, but not phosphoethanolamine, potentiates the effects of insulin, phosphocholine, and ATP on DNA synthesis in NIH 3T3 cells. Eur J Biochem 250: 395-402.

Komoroski RA, Holder JC, Pappas AA, Finkbeiner AE (2011) ${ }^{31}$ P NMR of phospholipid metabolites in prostate cancer and benign prostatic hyperplasia. Mag Reson Med 65: 911-913.

Koren R., Ben Meir D, Langzam L, Dekel Y, Konichezky M, Baniel J, Livne PS, Gal R, Sampson SR (2004) Expression of protein kinase C isoenzymes in benign hyperplasia and carcinoma of prostate. Oncol Rep 11: 321-326.
Kume H, Sasaki H (2006) Ethanolamine modulates DNA synthesis through epidermal growth factor receptor in rat hepatocytes. In Vitro Cell Dev BiolAnimal 42: 20-26.

Kurhanewicz J, Vigneron DB (2008) Advances in MR spectroscopy of the prostate. Magn Reson Imaging Clin N Am 16: 697-710.

Lahn M, Sundell K, Gleave M, Ladan F, Su C, Li S, Ma D, Paterson BM, Bumol TF (2004) Protein kinase C- $\alpha$ in prostate cancer. BJU Int 93: 1076-1081.

Li H, Wang X, Li N, Qiu J, Zhang Y, Cao X (2007) hPEBP4 resists TRAILinduced apoptosis of human prostate cancer cells by activating Akt and deactivating ERK1/2 pathways. J Biol Chem 282: 4943-4950.

Li H, Huang F, Fan L, Jiang Y, Wang X, Li J, Wang Q, Pan H, Sun J, Cao X, Wang X (2014) Phosphatidyylethanolamine-binding protetin 4 is associated with breast cancer metastasis through Src-mediated Akt tyrosine phosphorylation. Oncogene 33: 4589-4598.

Lipton BA, Yorek MA, Ginsberg BH (1988) Ethanolamine and choline transport in cultured bovine aortic endothelial cells. J Cell Physiol 137: 571-576.

Luberto C, Hannun YA (1998) Sphingomyelin synthase, a potential regulator of intracellular levels of ceramide and diacylglycerol during SV40 transformation. J Biol Chem 273: 14550-14559.

Mazie A R, Spix J K, Block E R, Achebe H B, Klarlund J K (2006) Epithelial cell motility is triggered by activation of the EGF receptor through phosphatidic acid signalling. J Cell Sci 119: 1645-1654.

McDermott M, Wakelam M J O, Morris A J (2004) Phospholipase D. Biochem Cell Biol 82: 225-253.

Mimeault M, Pommery N, Wattez N, Bailly C, Henichart J P (2003) Anti-proliferative and apoptotic effects of anandamide in human prostatic cancer cell lines: implication of epidermal growth factor receptor down-regulation and ceramide production. Prostate 56: 1-12.

Mintz A, Wang L, Ponde DE (2008) Comparison of radiolabelled choline and ethanolamine as probes for cancer detection. Cancer Biol Ther 7: 742-747.

Morris AJ, Frohman MA, Engebrecht J (1997) Measurement of phospholipase D activity. Anal Biochem 252: 1-9.

Muller-Decker K (1989) Interruption of TPA-induced signals by an antiviral and antitumoral xanthate compound: inhibition of a phospholipase C-type reaction. Biochem Biophys Res Comm 162: 198-205.

Murakami H, Masui H, Sato GH, Sueoka N, Chow TP, Kano-Sueoka T (1982) Growth of hybridoma cells in serum-free medium: Ethanolamine is an essential component. Proc Natl Acad Sci USA 79: 1158-1162.

Patel MI, Singh J, Niknami M, Kurek C, Yao M, Lu S, Maclean F, King NJC, Gelb MH, Scott KF, Russell PJ, Boulas J, Dong Q (2008) Cytosolic phospholipase $\mathrm{A}_{2}$-a: A potential therapeutic target for prostate cancer. Clin Cancer Res 14: 8070-8079.

de Petrocellis L, Melck D, Palmisano A, Bisogno T, Laezza C, Bifulco M, Di Marzo V (1998) The endogenous cannabinoid anandamide inhibits human breast cancer cell proliferation. Proc Natl Acad Sci USA 95: 8375-8380.

Pettitt T R, Martin A, Horton T, Liossis C, Lord J M, Wakelam M J O (1997) Diacylglycerol and phosphatidate generated by phospholipases C and D, respectively, have distinct fatty acid composituions and functions. J Biol Chem 272: 17354-17359.

Pettitt T R, McDermott M, Saqib K M, Shimwell N, Wakelam M J O (2001) Phospholipase D1b and D2a generate structurally identical phosphatidic acid species in mammalian cells. Biochem J 360: 707-715.

Podo F (1999) Tumour phospholipid metabolism. NMR BioMed 12: 413-439.

Podo F, Sardanelli F, Iorio E, Canese R, Carpinelli G, Fausto A, Canevari S (2007) Abnormal chlorine phospholipid metabolism in breast and ovary cancer: molecular basis for noninvasive imaging approaches. Curr. Med. Imag. Rev 3: 123-137.

Ramirez de Molina A, Rodriguez-Gonzalez A, Gutierrez R, Martinez-Pineiro L, Sanchez JJ, Bonilla F, Rosell R, Lacal JC (2002) Overexpression of choline kinase is a frequent feature in human tumor-derived cell lines and in lung, prostate and colorectal cancers. Biochem Biophys Res Comm 296: 580-583.

Ramirez de Molina A, Gallego-Ortega D, Sarmentero-Estrada J, Lagares D, del Pulgar TG, Bandres E, Garcia-Foncillas J, Lacal JC (2008) Choline kinase as a link connecting phospholipid metabolism and cell cycle regulation: implications for cancer therapy. Int J Biochem Cell Biol 40: 1753-1763.

Rizzo M A, Shome K, Watkins S C, Romero G (2000) The recruitment of Raf- 1 to membranes is mediated by direct interaction with phosphatidic acid and is independent of association with Ras. J Biol Chem 275: 23911-23918.

Rumsby M, Schmitt J, Sharrard M, Rodrigues G, Stower M, Maitland N (2011) Human prostate cell lines from normal and tumorigenic epithelia differ in 
the pattern and control of choline lipid headgroups released into the medium on stimulation of protein kinase C. Brit J Cancer 104: 673-684.

Sarfaraz S, Afaq F, Adhami V M, Mukhtar H (2005) Cannabinoid receptor as a novel target for the treatment of prostate cancer. Cancer Res 65(5): $1635-16441$.

Sarfaraz Afaq F, Adhami VM, Malik A, Mukhtar H (2006) Cannabinoid receptor agonist-induced apoptosis of human prostate cancer cells LNCaP proceeds through sustained activation of ERK1/2 leading to $G_{1}$ cell cycle arrest. J Biol Chem 281: 39480-39491.

Sarri E, Pardo R, Fensome-Green A, Cockcroft S (2003) Endogenous phospholipase D2 localises to the plasma membrane of RBL-2H3 mast cells and can be distinguished from ADP ribosylation factor-stimulated phospholipase D1 activity by its specific sensitivity to oleic acid. Biochem $J$ 369: 319-329.

Sasaki H, Kume H, Nemoto A, Narisawa S, Takahashi N (1997) Ethanolamine modulates the rate of rat hepatocyte proliferation in vitro and in vivo. Proc Natl. Acad Sci USA 94: 7320-7325.

Schmid P C, Wold L E, Krebsbach R I, Berdyshev E V, Schmid H H O (2002) Anandamide and other $N$-Acylethanolamines in human tumors. Lipids 37: 907-912.

Schnabel P, Gas H, Nohr T, Bohm M (1997) G protein-independent stimulation of human myocardial phospholipase $\mathrm{C}$ by mastoparan. Brit J Pharm 122: 31-36.

Singer S, Souza K, Thilly WG (1995) Pyruvate utilisation, phosphocholine and adenosine triphosphate (ATP) are markers of human breast tumour progression: $\mathrm{A}^{31} \mathrm{P}$ - and ${ }^{13} \mathrm{C}$-nuclear magnetic resonance (NMR) spectroscopy study. Cancer Res 55: 5140-5145.

Singh A T K, Frohman M A, Stern P H (2005) Parathyroid hormone stimulates phosphatidylethanolamine hydrolysis by phospholipase D in osteoblastic cells. Lipids 40(11): 1135-1140.

Spiegel S, Milstien S (2002) Sphingosine 1-phosphate, a key cell signalling molecule. J Biol Chem 277: 25851-25854.

Stace C L, Ktistakis N T (2006) Phosphatidic acid- and phosphatidylserinebinding proteins. Biochim Biophys Acta 1761: 913-926.

Stewart JR, O'Brian CA (2005) Protein kinase C- $\alpha$ mediates epidermal growth factor transactivation in human prostate cancer cells. Mol Cancer Ther 4: 726-732.

Sun YH, Gao X, Tang YJ, Xu CL, Wang LH (2006) Androgens induce increases in intracellular calcium via a $G$ protein-coupled receptor in LNCaP prostate cancer cells. J Androl 27: 671-678.

Suburu J, Chen Y Q (2012) Lipids and prostate cancer. Prost Lipid Med 98: 1-10. Swanson MG, Keshari KR, Tabatabai ZL, Simko JP, Shinohara K, Carroll PR, Zektzer AS, Kurhanewicz J (2008) Quantification of choline- and ethanolamine-containing metabolites in human prostate tissues using ${ }^{1}$ H HR-MAS total correlation spectroscopy. Mag Reson Med 60: 33-40.
Tian Y, Corkey RF, Yaney GC, Goforth PB, Satin LS, de Vargas LM (2009) Differential modulation of L-type calcium channel subunits by oleate. Am J Physiol Endocrinol Metab 294: E1178-E1186.

Toschi A, Lee E, Xu L, Garcia A, Gadir N, Foster D A (2009) Regulation of mTORC1 and mTORC2 complex assembly by phosphatidic acid: competition with rapamycin. Mol Cell Biol 29(6): 1411-1420.

Ueda N, Tsuboi K, Uyama T (2010) N-acylethanolamine metabolism with special reference to $\mathrm{N}$-acylethanolamine-hydrolysing acid amidase (NAAA). Prog Lipid Res 49: 299-315.

Vance DE, Ridgway ND (1988) The methylation of phosphatidylethanolamine. Prog Lipid Res 27: 61-79.

Vance D E, Li Z, Jacobs R L (2007) Hepatic phosphatidylethanolamine $\mathrm{N}$-methyltransferase, unexpected roles in animal biochemistry and physiology". J. Biol. Chem. 282(46): 33237-33241.

Vance JE (2008) Phosphatidylserine and phosphatidylethanolamine in mammalian cells: two metabolically related aminophspholipids. J Lipid Res 49: 1377-1387.

van Dijk MCM, Muriana FJG, de Widt J, Hilkmann H, van Blitterswijk WJ (1997) Involvement of phosphatidylcholine-specific phospholipase C in platelet-derived growth factor-induced activation of the mitogen-activated protein kinase pathway in Rat-1 fibroblasts. J Biol Chem 272: 11011-11016.

Yorek MA, Dunlap JA, Spector AA, Ginsberg BH (1986) Effect of ethanolamine on choline uptake and incorporation into phosphatidylcholine in human Y79 retinoblastoma cells. J Lipid Res 27: 1205-1213.

Wang J, Zhao L-Y, Uyama T, Tsubol K, Wu X-X, Kakehi Y, Ueda N (2008) Expression and secretion of $\mathrm{N}$-acylethanolamine-hydrolysing acid amidase in human prostate cancer cells. J Biochem 144: 685-690.

Wang X, Devaiah S P, Zhang W, Welti R (2006) Signaling functions of phosphatidic acid. Prog Lipid Res 45: 250-278.

Weisser H, Krieg M (1998) Fatty acid composition of phospholipids in epithelium and stroma of human benign prostatic hyperplasia. The Prostate 36: 235-243.

Xie Y, Gibbs T C, Meier K E (2002) Lysophosphatidic acid as an autocrine and paracrine mediator. Biochim. Biophys.Acta 1582: 270-281.

Zhou X, Mao J, Ai J, Deng Y, Roth M R, Pound C, Henegar J, Welti R, Bigler S A (2012) Identification of plasma lipid biomarkers for prostate cancer by lipidomics and bioinformatics. PLoS One 7(11): e48889.

This work is published under the standard license to publish agreement. After 12 months the work will become freely available and the license terms will switch to a Creative Commons AttributionNonCommercial-Share Alike 3.0 Unported License. 